\title{
Comparison of the Effects of Treadmill Trainings on Walking and Balance Functions by Increasing the Speed and Incline in Chronic Patients with Stroke
}

\author{
Kronik İnme Hastalarında Hız veya Ĕ̆im Artırılarak Yapılan Koşu Bandı Ĕ̆itimlerinin \\ Yürüme ve Denge Fonksiyonlarına Olan Etkilerinin Karşılaştırılması
}

\author{
(1) Çağrı Alıpsatıc11, (1) Nuray Alaca², (1) Mehmet Kerem Canbora3 \\ ${ }^{1}$ Aktif Medical Center, Clinic of Physiotherapy and Rehabilitation, Istanbul, Turkey \\ 2Acibadem Mehmet Ali Aydinlar University Faculty of Health Sciences, Department of Physiotherapy and Rehabilitation, Istanbul, Turkey \\ 3Uskudar University Faculty of Health Sciences, Department of Orthopedics and Traumatology, Istanbul, Turkey
}

\begin{abstract}
Objective: Improvement of walking is an important goal in stroke rehabilitation. This aim of this study was to compare the effects of treadmill training on walking and balance functions by increasing the speed or incline in patients with chronic stroke.

Materials and Methods: Twenty-eight patients with chronic stroke who had symptoms of motor function plateau, were included in the study. Patients were divided into two groups: conventional treatment and treadmill training with increased speed [group (CTIS); $\mathrm{n}=14$ ] and conventional treatment and treadmill training with increased incline [group (CTII); $\mathrm{n}=14$ ]. The rehabilitation program was conducted three times per week for eight weeks. The following tests were performed before and after treatment: six-minute walking test (6MWT), ten-meter walking test (10MWT), Berg Balance scale, Beck Depression inventory, stride length, and cadence assessments.

Results: In the pre- and post-treatment evaluations of both groups, walking and balance function and depression scale scores improved statistically (p<0.001). The between-group comparisons demonstrated that the CTIS group had a statistically significant improvement in the evaluation of $6 \mathrm{MWT}$ ( $\mathrm{p}=0.023$ ), 10MWT $(\mathrm{p}=0.006)$, stride length $(\mathrm{p}=0.004)$, and cadence $(\mathrm{p}<0.001)$ compared with the CTII group.

Conclusion: Together, our data demonstrate that walking training on a treadmill has positive results on walking and balance functions, as well as the emotional levels of patients with chronic stroke in the assumed plateau period. We anticipate that treadmill walking training performed with increased speed may be more beneficial than increasing the incline in patients with stroke.
\end{abstract}

Keywords: Stroke, plateau, treadmill, incline, speed

$\ddot{O} \mathbf{z}$

Amaç: Yürüyüşün iyileştirilmesi inme rehabilitasyonunda önemli bir hedeftir. Bu çalışmada, kronik inmeli hastalarda; hız veya eğim artırılarak yapılan koşu bandı eğitiminin konvansiyonel tedavi ile birlikte uygulanmasının yürüme parametreleri ve denge fonksiyonları üzerine etkisinin karşılaştırılması amaçlanmaktadır.

Gereç ve Yöntem: Motor fonksiyonlarında duraksama olduğunu (plato) bildiren 28 kronik inmeli hasta çalışmaya alındı. Hastalar; konvansiyonel tedavi ve hızı artırılarak yapılan koşu bandı eğitim grubu [(HKBE); n=14] ile konvansiyonel tedavi ve eğim artırılarak yapılan koşu bandı eğitim grubu [(EKBE); n=14] olarak iki gruba ayrıldı. Rehabilitasyon programı haftada üç kez sekiz hafta boyunca uygulandı. Hastalara tedavi öncesi ve sonrasında; altı dakika yürüme testi (6DYT), on metre yürüme testi (10MYT), Berg Denge skalası, Beck Depresyon ölçeği, adım uzunluğu ve kadans değerlendirmeleri yapıldı.

Bulgular: Her iki grubun tedavi öncesi ve sonrası de ğerlendirmelerinde; yürüme ile denge fonksiyonları ve depresyon ölçeği grup içlerinde istatistiksel olarak anlamlı şekilde iyileşmişti ( $\mathrm{p}<0,001)$. Grupların birbiri ile karşılaştırılmasında HKBE grubu 6DYT ( $\mathrm{p}=0,023), 10 \mathrm{MYT}(\mathrm{p}=0,006)$, adım uzunluğu ( $\mathrm{p}=0,004)$ ve kadans $(\mathrm{p}=0,000)$ değerlendirmelerinde istatistiksel olarak anlamlı şekilde EKBE grubuna göre daha fazla iyileşme gösterdi.

Sonuç: Koşu bandı ile yapılan yürüyüş eğitiminin plato döneminde olduğu varsayılan kronik inme hastalarında yürüme ve denge fonksiyonları ile duygu durum düzeylerinde olumlu sonuçları olduğunu gördük. Ayrıca, koşu bandı eğitimi yaptırılırken eğimin artırılmasından daha çok hızın artırılarak yapılan yürüyüş eğitiminin inme hastalarında daha yararlı olabileceğini öngörmekteyiz.

Anahtar Kelimeler: İnme, plato, koşu bandı, eğim, hız

Address for Correspondence/Yazışma Adresi: Nuray Alaca MD, Acibadem Mehmet Ali Aydinlar University Faculty of Health Sciences,

Department of Physiotherapy and Rehabilitation, Istanbul, Turkey

Phone: +90 5324251290 E-posta: nuraygecer@hotmail.com ORCID: orcid.org/0000-0003-3034-9388

Received/Geliş Tarihi: 01.02.2020 Accepted/Kabul Tarihi: 18.08.2020

${ }^{\circ}$ Copyright 2020 by Turkish Neurological Society

Turkish Journal of Neurology published by Galenos Publishing House. 


\section{Introduction}

Ischemic or hemorrhagic stroke, which is a cerebrovascular disease of the central nervous system, is the main cause of locomotor disability in adults $(1,2)$. Rehabilitation interventions aim to improve the performance of daily living activities in patients with acute or chronic stroke ( $>6$ months). However, despite these treatments, many people are still significantly disabled at discharge (2). Considering the expected increase in the incidence and prevalence of stroke, and therefore the increase in the number of individuals expected to have stroke-related disorders, determining appropriate care plans for patients with stroke is a priority (3).

Despite improvements in motor function in the early period after stroke, patients often show a "plateau" or pause with slowing motor recovery in the chronic stages. This situation often causes patients to leave physiotherapy and rehabilitation (PTR). It has been determined that the reasons for this are that as the stroke becomes more chronic and/or as patients do not respond positively to motor rehabilitation (when they reach the default plateau), termination of motor rehabilitation is often recommended, insurance systems require it, or the patient and family want it $(4,5)$. However, many studies have shown that performing certain motor tasks provides significant improvements in clinically functional markers, even after the supposed plateau phase (6).

Most stroke survivors can walk independently, but only a small proportion can walk with sufficient speed and endurance to enable them to function in the community (7) because they have impaired motor control and balance, which seriously affects their ability to walk, causing dependency, increased load on their caregivers, and society. The improvement of walking is therefore an important goal in stroke rehabilitation. Many new methods have been presented for gait rehabilitation in patients with stroke (8). It has been reported that walking training with a treadmill, among these methods, may be more effective than walking training on a flat surface (9). In addition, it has been reported that approximately 4000 steps are taken in an hour of walking on the treadmill, whereas this number is approximately 400 steps in classic PTR training (10). It is thought that this excessive repetition may have a positive effect (through motor learning), especially in a patient on a plateau $(10,11)$. In addition, the treadmill offers different densities for walking and has handrails that can aid the performance of the individual (12).

In a study conducted by Lau and Mak (8) on patients with subacute stroke, they found that after ten sessions of treatment, training with increased speeds of the treadmill caused better results in walking speed and stride length (SL) compared with fixed-speed treadmill training. Ahmed et al. (13) reported that running an incline treadmill showed more positive improvements in walking and balance than a non-incline treadmill. As far as we know, no study has investigated the differences between treadmill training with increasing speeds and treadmill training with an increasing incline. Therefore, in the current study, it was aimed to compare the effect of treadmill training with conventional therapy on walking parameters and balance functions in patients with chronic stroke in the plateau period.

\section{Materials and Methods}

\section{Study Protocol and Patients}

The study was created with a randomized, controlled prospective design. Ethical approval (0.05.0.06/2018/821) was obtained from Uskudar University Non-interventional Ethics Committee for the study. Thirty patients with chronic stroke who were admitted to the PTR department of the Aktif Medicine Center between November 2018 and June 2019 and reported a cessation of motor functions were included in the study. Verbal and written consents of the patients were obtained. Patients with bilateral hemispheric, cerebellar or brainstem lesions, receptive aphasia, significant cognitive deficit, depression, visual field deficiency and orthopedic problems affecting participation were excluded from the study. The inclusion criteria were as follows $(10,14,15)$;

- Age range 20-60 years

- Having had a stroke 6 months-2 years ago

- Having had one stroke

- Lower extremity Brunnstrom stage 4 or above

- Not having performed PTR in the last 6 months

- Ability to walk independently in a 10-meter walk and complete this walk under $<0.9 \mathrm{~m} / \mathrm{sec}$

- Completing the treadmill exercise at $80 \%$ of the maximum walking speed

- Ability to complete the 6-minute walking test (6MWT)

- No additional neurologic disorders

- No cardiac instability problem

The study power was calculated using the G*Power V.3.1.7 (Kiel University, Kiel, Germany) program. It was calculated that 20 patients in total were needed to achieve the power ratio of the study as $95 \%$ with an error margin of 0.05 at a confidence level of $95 \%(15,16)$. Assuming that there might be patients who would leave the study, the total number of patients was calculated as 30 . Thirty patients were randomly divided into two groups using the block randomization method with the help of the random allocation software program:

i. Conventional therapy and treadmill training with increased speed (CTIS) (group CTIS, $\mathrm{n}=15$ )

ii. Conventional therapy and treadmill training with increased incline (CTII) (group CTII, $\mathrm{n}=15$ )

Each patient was treated 3 days per week for 8 weeks.

\section{Rehabilitation Programs}

All patients received half an hour of conventional therapy, electrical stimulation (15 minutes), and then half an hour of treadmill training. In conventional treatment, a rehabilitation program that included passive/active assistive/active normal range of motion exercises, antispastic strengthening exercises targeting the muscles that aid walking, and recommendations to prevent complications was performed for half an hour (17). After the rehabilitation program, electrical stimulation was performed for 15 minutes. Electrical stimulation was applied to the quadriceps and tibialis anterior muscles (the basic muscles that aid walking) using a Globus Premium 400 device. A strengthening program with electrical stimulation $(70-100 \mathrm{~Hz}, 150 \mu \mathrm{s}, 10$-sec relaxation with 6-sec contraction) was performed for 15 minutes.

In the treadmill programs, the maximum speeds of all patients were first determined with the 10-meter walking test (10MWT). 
The basic speed on the treadmill was determined by taking $80 \%$ of their maximum speeds. Both groups were made accustomed to a 30 -minute treadmill exercise training with no incline and $80 \%$ of their maximum speed for a week.

In the CTIS group, treadmill training was given with $80 \%$ of the maximum speed in the first week and then by increasing the speed every week by $10 \%$ of the previous week (8). In the CTII group, the fixed speed was determined as $80 \%$ of the maximum speed, and the inclination was set to $3 \%$ in the first week, after which it was increased by $1-1.5 \%$ every week according to the condition of the patient. The patient's condition was scored using the Rated Perceived Exertion Scale between 6 and 20 during exercise. Patients were allowed to exercise at a level of 11-14 (from light to slightly difficult) (18). Patients who felt bad were rested and re-enrolled after 5 minutes. Patients who rested twice in the same session did not receive the treatment that day. Patients who could not tolerate three consecutive treatments were excluded from the study. Each patient received a 30-minute treadmill training for 8 weeks, 3 days a week.

\section{Evaluations}

The following evaluation methods were applied to the patients before and after treatment.

\section{Ten-meter Walk Test}

The patients were asked to walk at their normal speed and then at their maximum speed in the previously measured 10-meter area. The time was started with the patient's foot on the starting line and ended when the patient crossed the finish line. Two measurements were made and the best value was recorded in meters/second (m/sec) (19).

\section{Six-minute Walk Test}

The test was developed to measure the functional walking capacity of patients with cardiovascular or respiratory system disorders. Since then, it has been used for evaluations in diseases with walking problems and patients with stroke (20). For the 6MWT, a 30-meter-long corridor was determined. A pontoon was placed at the start and finish points and the corridor was marked with a line every 1 meter. The distances the patients walked at the end of 6 minutes was recorded in meters.

\section{Berg Balance Scale (BBS)}

The BBS is often used in clinical studies to evaluate postural control and predict falling risk. In stroke rehabilitation, it is also used to predict the duration of hospital stay and the possibility of a need for care after discharge or living independently. The scale contains 14 instructions and each instruction is scored between " $0-4$ " by observing the performance of the patient. If the patient cannot perform the activity, " 0 " points are given, and if the patient completes the activity independently, "4" points are given. The highest score is $56,0-20$ points indicate imbalance, $21-40$ points indicate acceptable balance, $41-56$ points indicate the presence of good balance. It takes between 10 and 20 minutes to complete the scale (21).

\section{Beck Depression Inventory (BDI)}

The BDI was used to determine the mood level in the patients before and after the study. The scale, which includes 21 questions consisting of four options, asks how the person felt in the last week.
Each question is scored between 0 and 3. The highest score that can be obtained is 63. The scores between 0-9 are evaluated as minimal depressive symptoms, 10-16 as mild depressive symptoms, 17-29 as moderate depressive symptoms, and 30-63 as severe depressive symptoms (22).

\section{Cadence and Stride Length}

The number of steps taken in a minute is called cadence. Measurements were made with a pedometer attached to the patient on a 30-meter track. SL is the distance between the heel contact point of one foot and that of the other foot. The patient was asked to step on the meter fixed on the ground and the measurement was recorded. It was applied only to the affected extremity (23).

\section{Statistical Analysis}

The Statistical Package for the Social Sciences version 21.0 (SPSS Inc., Chicago, IL, USA) software was used for the analysis of the data. Categorical variables are expressed as number and frequency (percentage), and numerical data are expressed as mean \pm standard error. Whether the data had normal distribution was evaluated using the Shapiro-Wilk test. The paired-samples t-test was used to compare the pre-treatment and post-treatment evaluations within the group. In comparing the groups with each other, analysis of group and time-dependent changes for each evaluation criterion was performed using repeated-measures ANOVA. A p value $<0.05$ was considered statistically significant.

Effect size (ES) can be expressed as the expected difference between two averages or two ratios according to the outcome variable of interest to reveal a clinically significant difference. This is an indication of the significance of the research results in practice. It is the ratio of the difference between the means to the standard deviation before treatment. ES is interpreted as described by Cohen: $<0.20=$ small effect, $0.20-0.50=$ moderate effect, and $>0.80=$ large effect (24).

\section{Results}

Approximately 30 patients who met the inclusion criteria were evaluated. During the study, one patient was excluded from the study because of another stroke. One patient was excluded from the study because he did not attend in accordance with the working days. The final analysis was completed with 28 patients. Eleven of the patients were female (39.29\%), 17 were male $(60.71 \%)$. The mean age of all patients was $42.3 \pm 12.40$ years (mean age \pm standard error). The sociodemographic characteristics of the groups are shown in Table 1. There was no statistical difference between the sociodemographic characteristics of the groups $(\mathrm{p}>0.05$, Table 1).

In the pre- and post-treatment evaluations of both groups, balance and walking functions and depression scale scores improved significantly within the group ( $<<0.001$, Table 2$)$. In addition, the ES (ES $\geq 0.55$ ) of the CTIS group was greater than that of the CTII group (ES $\geq 0.22$ ), except for the BBS. Only in the BBS, CTII (ES=0.62) showed a slightly greater ES than CTIS $(\mathrm{ES}=0.47)$ (Table 2).

In the comparison of the groups, the CTIS group showed a statistically significant improvement in terms of the 6MWT $(\mathrm{p}=0.023), 10 \mathrm{MWT}(\mathrm{p}=0.006)$, SL $(\mathrm{p}=0.004)$, and cadence $(\mathrm{p}<0.001)$ compared with the CTII group (Table 2$)$. 


\section{Discussion}

After a stroke, many impairments in walking functions are observed, such as decreased walking speed, impaired symmetry, decreased SL, and increased stance phase duration in the affected limb. In addition, dynamic balance function is impaired in patients due to impairments in motor, sensory, and cognitive functions. Therefore, improvement in walking function, which will be provided with walking training, is an important goal in stroke rehabilitation $(8,13)$. In the present study, in patients with chronic stroke, it was aimed to compare the effects of increasing incline treadmill training and conventional therapy with increasing speed treadmill training and conventional therapy on walking parameters and balance functions. It was observed that both types of treadmill training given for eight weeks had positive effects on balance, walking functions, and mood in patients with chronic stroke. In addition, in the comparison of the groups, it was determined that treadmill training with increasing speed significantly improved walking functions compared with treadmill training with increased incline.

Treadmill training is widely used during rehabilitation after stroke, especially to increase dynamic balance and walking functions. Ilunga Tshiswaka et al. (12) reviewed exercise studies

\begin{tabular}{|c|c|c|c|}
\hline Parameters & CTIS & CTII & $\mathrm{p}$ \\
\hline Age & $44.8 \pm 12.33$ & $39.8 \pm 12.35$ & 0.821 \\
\hline Male & $8(57.14 \%)$ & $9(64.29 \%)$ & \multirow{2}{*}{0.267} \\
\hline Female & $6(32.86 \%)$ & $5(35.71 \%)$ & \\
\hline Right & $5(35.71 \%)$ & $4(38.58 \%)$ & \multirow[t]{2}{*}{0.464} \\
\hline Left & $9(64.29 \%)$ & $10(71.42 \%)$ & \\
\hline Dominant hemisphere involvement & $4(38.58 \%)$ & $3(21.45 \%)$ & \multirow{2}{*}{0.690} \\
\hline Non-dominant hemisphere involvement & $10(71.42 \%)$ & $11(78.55 \%)$ & \\
\hline
\end{tabular}

Table 2. Comparison of balance and walking functions and mood levels within and between groups and effect size

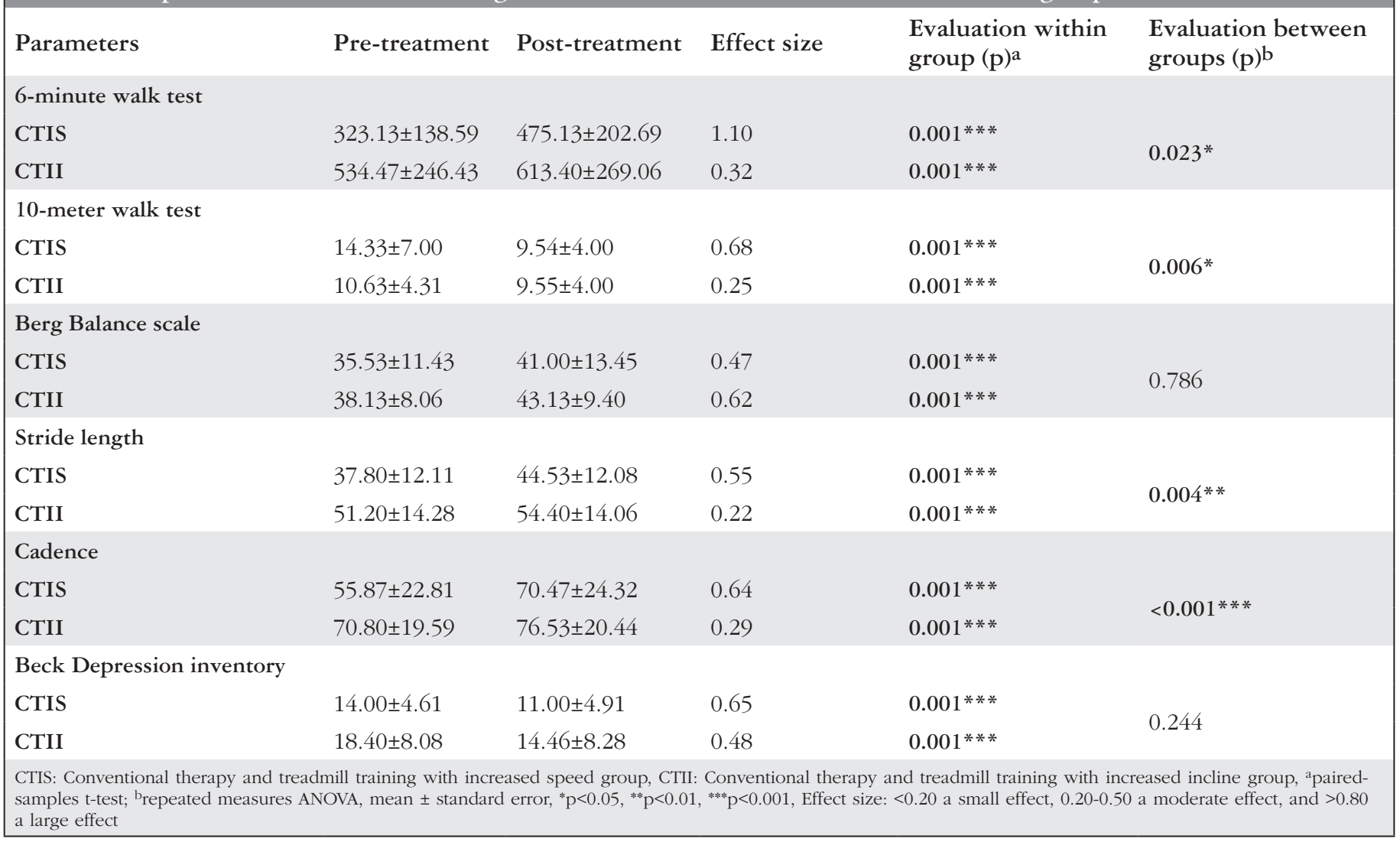


performed with treadmills in patients with stroke in 2018. In these studies, treadmill training was examined in different ways. Among them, there are studies conducted with a bodyweightsupported treadmill, visual and auditory stimuli, or using auxiliary devices, and there are also studies comparing normal walking (floor) and treadmill training. Studies have shown that all these types of walking training improve walking function, similar to our study in stroke rehabilitation (25). Studies have reported that normal walking training provided greater improvement than bodyweight-supported treadmill training (26), but other studies have documented opposing findings $(9,16)$. In addition, there are studies reporting that treadmill training is superior to normal walking training $(27,28)$. In the present study, the simple form of treadmill training was used, which was reported to show positive results in chronic patients with stroke. Because bodyweight supported treadmill gait training, which can be done with visual and auditory stimuli, or using auxiliary devices, is an expensive and complicated treatment that is not available in every physiotherapy unit.

In their study, Pohl et al. (6) compared classic physiotherapy walking training and treadmill training with increasing speed in patients with stroke, and stated that training with increasing speed yielded better results. Lau and Mak compared speed-dependent treadmill training and constant speed treadmill training in patients with subacute stroke, and they showed that increasing the speed, similar to our study, provided an increase in SL and speed compared with the control group (8).

In a study conducted with patients with chronic stroke, it was reported that during the first contact and swing phase of incline treadmill training, it promoted angular changes in the hip, knee, and ankle angle, such as an increase in the amplitude of hip and knee motion, and that it also increased the stance phase duration in the paretic lower extremity (29). Gama et al. (30) investigated the effect of running bodyweight-supported treadmill training with or without incline in patients with stroke. They stated that running incline treadmill training increased SL and speed. Ahmed et al. (13) reported that incline treadmill training showed more positive improvements in walking and balance compared with non-incline treadmill training. They reported that the repetition of treadmill training by increasing incline had an effect on motor learning and increased balance and walking function by increasing lower extremity muscle strength.

To the best of our knowledge, the current study is the first in the literature to compare treadmill training with increasing speed or incline in patients with chronic stroke. In our study, it was determined that patients in both groups showed statistically significant improvements in their mood, walking, and balance scores after the treatment compared with the pre-treatment period. Therefore, we have seen that treadmill training performed in addition to conventional treatment may have potential benefits in patients with chronic stroke who are presumed to be in the plateau period. However, we could not use objective methods such as electromyography and gait analysis to investigate the cause of this development. This was the limitation of our study. In addition, the inclusion of chronic patients with lower extremity Brunnstrom stage 4 or above in the study did not support the prediction that spasticity did not remain in the lower extremity. We could not discuss the effect of this situation with the data because we could not evaluate the spasticity values. This is another limitation of our study.

\section{Conclusion}

In the comparison of the two groups, we determined that the speed treadmill training caused a more significant increase in walking functions compared with the incline treadmill training. This situation led us to predict that it would be more important to increase the speed than to increase the incline of the treadmill. However, more studies are needed on this subject.

Ethics

Ethics Committee Approval: Ethical approval (0.05.0.06/2018/821) was obtained from Uskudar University Non-Interventional Ethics Committee for the study.

Informed Consent: Verbal and written consents of the patients were obtained.

Peer-review: Externally and internally peer-reviewed.

\section{Authorship Contributions}

Surgical and Medical Practices: Ç.A., Concept: Ç.A., N.A., M.K.C., Design: Ç.A., N.A., M.K.C., Data Collection or Processing: Ç.A., N.A., Analysis or Interpretation: Ç.A., N.A., M.K.C., Literature Search: Ç.A., N.A., M.K.C., Writing:N.A., Ç.A.

Conflict of Interest: No conflict of interest was declared by the authors.

Financial Disclosure: The authors declared that this study received no financial support.

\section{References}

1. Yavuzer G, Selles R, Sezer N, et al. Mirror therapy improves hand function in subacute stroke: a randomized controlled trial. Arch Phys Med Rehabil 2008;89:393-398.

2. Hill K, Ellis P, Bernhardt J, Maggs P, Hull S. Balance and mobility outcomes for patients with stroke: A comprehensive audit. Aust J Physiother 1997; 43:173-180.

3. American Heart Association. Heart and stroke statistical update. 2003, Dallas: AHA

4. Page SJ, Gater DR, Bach-Y-Rita P. Reconsidering the motor recovery plateau in stroke rehabilitation. Arch Phys Med Rehab 2004;85:1377-1381.

5. Demain S, Wiles R, Roberts L, McPherson K. Recovery plateau following stroke: fact or fiction?. Disabil Rehabil 2006;28:815-821.

6. Pohl M, Mehrholz J, Ritschel C, Rückriem S. Speed-dependent treadmill training in ambulatory hemiparetic stroke patients: a randomized controlled trial. Stroke 2002;33:553-558.

7. Corr S, Bayer A. Poor functional status of patients with stroke after hospital discharge: Scope for intervention? Br J Occup Ther 1992;55:383-385.

8. Lau KW, Mak MK. Speed-dependent treadmill training is effective to improve gait and balance performance in patients with sub-acute stroke. J Rehabil Med 2011;43:709-713.

9. Werner C, Von Frankenberg S, Treig T, Konrad M, Hesse S. Treadmill training with partial body weight support and an electromechanical gait trainer for restoration of gait in subacute stroke patients: a randomized crossover study. Stroke 2002;33:2895-2901.

10. Moore JL, Hendron K, Hornby TG. Challenging the concept of a "plateau" in motor recovery poststroke using intensive locomotor training: a case study. American Physical Therapy Association Combined Sections Meeting. 2009.

11. Lang CE, MacDonald JR, Reisman DS, et al. Observation of amounts of movement practice provided during stroke rehabilitation. Arch Phys Med Rehabil 2009;90:1692-1698.

12. Ilunga Tshiswaka D, Bennett C, Franklin C. Effects of walking trainings on walking function among stroke survivors: a systematic review. Int J Rehabil Res 2018;41:1-13.

13. Ahmed GM, Fahmy EM, Elwishy AA, Assem KM, Zidan FS. Effects of Inclined Treadmill Training on Gait and Balance in Patients with stroke. N Y Sci J 2018;11:52-56. 
14. Srivastava A, Taly AB, Gupta A, Murali T. Rehabilitation interventions to improve locomotor outcome in chronic stroke survivors: A prospective, repeated-measure study. Neurol India 2015;63:347-352.

15. Hornby TG, Campbell DD, Kahn JH, et al. Enhanced gait-related improvements after therapist- versus roboticassisted locomotor training in subjects with chronic stroke: a randomized controlled study. Stroke 2008;39:1786-1792.

16. Ada L, Dean CM, Hall JM, Bampton J, Crompton S. A treadmill and overground walking program improves walking in persons residing in the community after stroke: a placebo-controlled, randomized trial. Arch Phys Med Rehabil 2003;84:1486-1491.

17. Otman S, Aksu S, Aras Ö, et al. Hemipleji Rehabilitasyonunda Nörofizyolojik Yaklaşımlar. 1.baskı, Hipokrat Kitapevi, Ankara-2001.

18. Moore GE, Durstine JL, Marsh AP. Framework. In: Durstine JL, Moore GE, eds: ACSM's Exercise management for persons with chronic diseases and disabilities. USA: Human Kinetics; 2003. p.5-15.

19. Shubert TE, Schrodt LA, Mercer VS, Busby-Whitehead J, Giuliani CA. Are scores on balance screening tests associated with mobility in older adults? J Geriatr Phys Ther 2006;29:35-39.

20. Dunn A, Marsden DL, Nugent E, et al. Protocol variations and six-minute walk test performance in stroke survivors: a systematic review with metaanalysis. Stroke Res Treat 2015;2015:484813.

21. Şahin F, Büyükavci R, Sağ S, Doğu B, Kuran B. Reliability and validity of the Turkish version of the berg balance scale in patients with stroke. Türk Fiz Tip Rehab Derg 2013;59:170-175.

22. Hisli N. Beck Depresyon Envanterinin Geçerliği Üzerine Bir Çalışma. Psikoloji Dergisi 1988;118-126.
23. Pease SW, Bowyer LB, Kadyan V. Human walking. In: Delisa JA, Gans MG, Walsh NE, eds. Physical Medicine and Rehabilitation, Principles and Practice. 4th ed. Philadelphia: Lippincott Williams and Wilkins; 2005: p. $155-168$.

24. Cohen J. Statistical power analysis for the behavioural sciences. New York: Academic Press; 1977.

25. Olawale O, Jaja S, Anigbogu C, Appiah-Kubi K, Jones-Okai D. Exercise training improves walking function in an African group of stroke survivors: a randomized controlled trial. Clin Rehabil 2011;25:442-450.

26. Combs-Miller SA, Kalpathi Parameswaran A, Colburn D, et al. Body weight-supported treadmill training vs. overground walking training for persons with chronic stroke: a pilot randomized controlled trial. Clin Rehabil 2016;28:873-884

27. Mackay-Lyons M. Aerobic treadmill training effectively enhances cardiovascular fitness and gait function for older person with chronic stroke. J Physiother 2012;58:271.

28. Park J, Park SY, Kim YW, Woo Y. Comparison between treadmill training with rhythmic auditory stimulation and ground walking with rhythmic auditory stimulation on gait ability in chronic patients with stroke: a pilot study. NeuroRehabilitation 2015;37:193-202.

29. Moreno CC, Mendes LA, Lindquist AR. Effects of treadmill inclination on the gait of individuals with chronic hemiparesis. Arch Phys Med Rehabil 2011;92:1675-1680.

30. Gama GL, de Lucena Trigueiro LC, Simão CR, et al. Effects of treadmill inclination on hemiparetic gait: controlled and randomized clinical trial. Am J Phys Med Rehab 2015;94:718-727. 